Јасмина Московљевић Поповић*

Филолошки факултет

Универзитет у Београду https://doi.org/10.18485/analiff.2018.30.1.9

$811.163 .41 ' 367.625$

Оригинални научни рад

Примљен: 18.06.2018.

Прихваћен: 25.09.2018.

\title{
ГЛАГОЛИ ТИПА „ВЛАДАТИ" У ИМПЕРСОНАЛНИМ КОНСТРУКЦИЈАМА С ПАРТИЦИПСКИМ ПАСИВОМ У САВРЕМЕНОМ СРПСКОМ ЈЕЗИКУ ${ }^{* *}$
}

\begin{abstract}
У раду је на грађи из савременог српског језика описан и анализиран један тип имперсоналне реченичне структуре формиране од глагола типа „владати” с предикатом у облику партиципског пасива и допуном у облику инструментала без предлога. Уз презентацију грађе из корпуса, издвојени су чланови ове глаголске класе и анализирана структурна и функционална својства реченица у оквиру којих се они реализују. Предложен је нов начин категоризације ових конструкција у односу на димензије [ \pm персонално] и [ \pm актив] и извршена иницијална анализа изван- и унутарјезичких процеса који омогућавају и условљавају појаву овог типа имперсоналних пасивних реченица у савременом српском језику.
\end{abstract}

Кључне речи: глаголска класа „владати”, допуна у инструменталу, имперсоналне конструкције, партиципски пасив, имперсонални пасив, савремени српски језик

1. Овај рад настао је са двојаким циљем: а) да се опишу и анализирају структурна и функционална својства имперсоналних реченица с предикатом у облику партиципског пасива и допуном у облику $\mathrm{NP}_{\text {ins }}$, илустрованих примерима (1)-(2); б) да се утврди постоји ли и колика је сличност између ових конструкција и пасивних конструкција формираних с транзитивним глаголом (примери (3)-(4)), као и да ли је, и на основу којих аргумената, имперсоналне конструкције овог типа могуће одредити као пасивне.

* Филолошки факултет, Студентски трг 3, e-mail: jasmina.moskovljevic@fil.bg.ac.rs

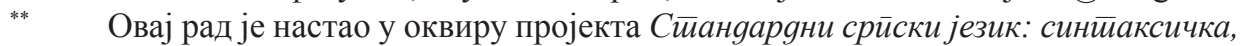

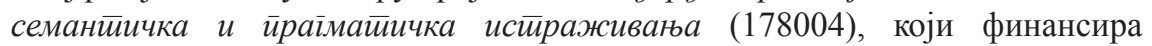
министарство за науку и технолошки развој Републике Србије. 
Јасмина Московљевић Поповић

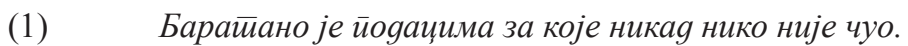

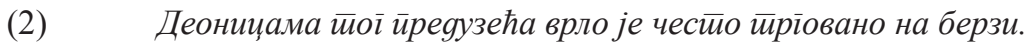

(3) Поменуйи су йоgаци за које никая нико није чуо.

(4) Деонице йов̄ йреgузећа јуйрос су йроgат̄е на берзи.

Иако се рад бави анализом само једног типа имперсоналних реченица с предикатом у облику партиципског пасива - конструкцијама формираним с глаголима типа „владати”, треба имати у виду да оне нису једини експонент овог реченичног типа у српском језику. Уз њих се убрајају и реченице формиране од глагола с директивном допуном у дативу (Прећено му је у више наврайа// Суђено му је у оgсусйву), затим оне које се формирају од комуникативних и глагола когнитивних процеса с допуном у облику „о” + $\mathrm{NP}_{\text {loc }}$ (О йоме је већ расирављано

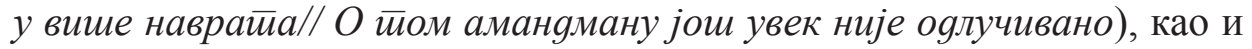
читав низ других реченичних типова. ${ }^{1}$

У досадашњим испитивањима синтаксичких структура и реченичних модела српског језика имперсоналне реченице овог типа остале су неописане и без јединствено прихваћене класификације. Томе је свакако допринело и то што реченице пасивне дијатезе у нашем језику и иначе нису, по тврдњи С. Танасића, довољно проучаване, а ,разлог за то је што се сматрало да пасивне реченице нису у духу нашег језика" (Танасић 2014:11). Да се ситуација битно променила (и још увек се мења) скренуо је пажњу још пре десетак година М. Радовановић пишући о главним темама „у српском језику и око њега”, када је ,...раст продуктивности пасивних структура, анонимизовање и имперсонализовање глаголских образовања и одговарајућих реченичних формација” уврстио у „...преглед инвентара језичких промена што би их ваљало са становишта стандарднојезичке норме преиспитати...” (Радовановић 2007: 244-245). Не доводећи у питање овај неспорни закључак, тежиште рада ипак почива на утврђивању структурних, категоријалних и функционалних својстава датих конструкција као првом и нужном кораку у анализи, док њихов нормативни статус остаје ван граница разматрања.

1 За потпунију листу синтаксичко-семантичких модела имперсоналних конструкција с глаголом у облику партиципског пасива у савременом српском језику в. Московљевић Поповић (у припреми). 
2. За дати тип конструкција карактеристично је да се у савременом српском језику конституише око глагола који припадају невеликој, али семантички јасно издиференцираној класи имперфективних ателичних глагола, ${ }^{2}$ који означавају различите облике управљања, манипулисања или руковања (нечим). Уз ове глаголе се допуна у кореспондентним активним реченицама реализује у облику именичке синтагме у инструменталу, који је још М. Ивић одредила као „изразито објекатски инструментал", уз напомену да се у неким индоевропским језицима у конструкцијама са овим глаголом јавља допуна у акузативу (Ивић 1954: 113-114). Такав је, на пример, случај са енглеским, у руском се, као и у српском, јавља инструментал, док се у чешком (Janda 2007), фарском и исландском (Jónsson 2009) објекатска допуна уз ове глаголе реализује у дативу. Постојање варијација у одабиру падежних облика које се уочава међу различитим језицима из исте породице, као и међу различитим гранама индоевропске породице упућује на закључак да је реч о појави која је у првом реду рекцијски, значи лексички детерминисана.

2.1. У прикупљеном корпусу су имперсоналне конструкције с партиципским пасивом потврђене са следећим глаголима: ${ }^{3}$ барайа-

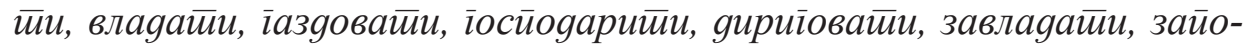

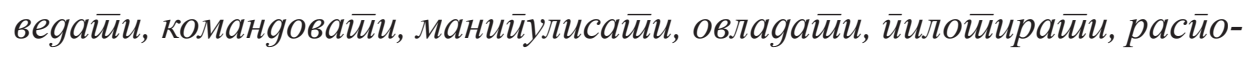

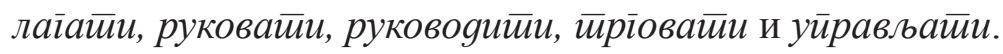

(5) Прије скоро мјесец дана у Административној служби града баратано је податком да је штета на 500 привредних објеката ... око 150 милиона... www. nezavisne.com.... радило се о сликама величине $2 \mathrm{~Gb}$, у резолуцији од $442 \mathrm{ppi}$, са којима је баратано као да се ради о маленим сличицама. www.benchmark.rs. Држава полиције, или опет Држава којом је владано резоном Државе... iluzionist54.blogspot.com. Хрватском и Трансилванијом, анектираним деловима Угарске, владано је такође нестручно. www.scribd.com. Уколико железницом није газдовано на домаћински начин, Војводина мора бити обештећена. www. autonomija.info. Ми сматрамо да овом имовином није газдовано на прави начин... www.rtv.rs. Приватним шумама је углавном неплански господарено, што је довело до деградације шумских станишта. www.pp-medvednica.hr. ...одакле је у наредних хиљаду година господарено судбином Европе, Азије и

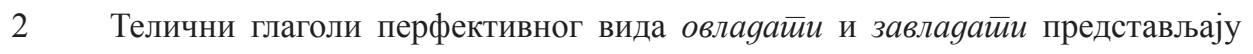
једине изузетке у прикупљеној грађи.

3 Грађа за овај рад ексцерпирана је из електронских извора - дигиталних верзија дневне штампе и публикација, као и из других извора доступних на интернету. Извори су наведени на крају рада. 
Јасмина Московљевић Поповић

Африке. www.mitropolija.me. ... да влада може затворити „одређене радикалне џамије” у Моленбек округу због страха да је то место одакле је дириговано нападом на Париз... www.pravda.rs. ... умногоме се одразило на уређивачку политику, којом је дириговано из једног центра. www.static.rtv.rs. Најприје је завладано војском. www.vasicrajko.blogspot.com. Са друге стране је за мање од 100 година завладано цијелим Блиским истоком, сјеверном Африком, па све до обала Шпаније. www.frontal.rs. Заповедано је елитном јединицом македонске тешке коњице... sr.istorija.wikia.com. Отмицу је ... организовала група терориста којом је командовано из иностранства. www.novosti.rs. ...здруженим снагама полиције, САЈ, АНБ, криминалаца и хулигана командовано је, супротно закону и правилима служби, од стране неовлашћених лица. www.nspm.rs. Лита Форд из групе „Бегунице” („The Runaways”) сведочи како је њоме манипулисано... www.pravoslavni-odgovor.com. Асад тврди да је манипулисано сликом дечака који је расплакао свет. www.blic.rs. У 19.веку је достигнуто оно што се чинило немогуће - овладано је узгојем орхидеја! www.cvecaragardenia.co.rs. Овладавање вишим нивоом подразумева да је овладано свим нивоима који се налазе испод тог нивоа. www.skolskisajt.in.rs Авионом је пилотирано ручно. www.kurir.rs ...продрли у сам командни центар ЦИА ... из кога је пилотирано летилицом.... www.magazin-tabloid.com. ... јавним овлашћењима није располагано у јавном интересу. www.transparentnost.org. ...за прикупљене податке располагано је информацијом о образовном статусу породица из којих ученици долазе. www. doiserbia.nb.rs. ... и њима је руковано на строго прописан начин. www.b92. net. Овим покретом руковано је из Београда. www.forum.b92.net. ... на којој је саградило зграде са канцеларијама из којих је руковођено градилиштем. http://www.vreme.com. Организацијом неколико пљачки, а затим и продајом украденог накита, руковођено је директно из Србије. www.rtrs.tv. Поморанџом је трговано у количини од 43 тоне... https://www.srbijadanas.com. У току 1996. године на Београдској берзи трговано је и робно-комерцијалним записима... www.belex.rs. ... и да ресурсима буде управљано тако да они могу да подрже и будуће генерације. https://singipedia.singidunum.ac.rs. Током првих десет година аутономном облашћу управљано је посредством војне управе... www.novosti.rs. ${ }^{4}$

2.2. Сви наведени примери имперсоналних конструкција са глаголима типа „владати” с предикатом у облику партиципског пасива и допуном у облику слободног инструментала деле одређена заједничка својства како међусобно, тако и са аналитичким пасивним конструкцијама формираним од транзитивних глагола с допуном у акузативу.

2.2.1. У семантичкој, тематској структури ових глагола налазе се два аргумента - агенс и тема, а глаголи означавају релацију у којој рефе-

4 За сваки глагол су због просторних ограничења наведена само по два примера мада их у прикупљеној грађи, посебно за неке глаголе, има много више. 
рент агенса контролише референта теме, руководи и располаже њиме, или има ингеренције над њим. Референт агенса носилац је семантичких обележја аниматности, свесности и интенционалности - истих оних које поседује и агенс великог броја транзитивних глагола који се реализују у пасивној конструкцији. Иако агенс у највећем броју реченица остаје синтаксички нереализован (чешће него што је то случај у пасивним конструкцијама с прелазним глаголима), његово је исказивање, бар у неким реченицама, могуће. Ако се реализује, јавља се у истом облику у коме се реализују и агентивне одредбе уз (праве) транзитивне глаголе - као предлошко-падежна конструкција og cйране + $\mathrm{NP}_{\text {gen }}$ :

(6) ...здруженим снагама полиције ... криминалаца и хулигана командовано је, супротно закону и правилима служби, од стране неовлашћених лица. www.nspm.rs. Председник ... сматра да је ... информацијама објављеним на друштвеним мрежама манипулисано од стране Русије и Саудијске Арабије. www.bnr.bg/sr. Као што је управљано целом Србијом од стране Отоманског царства. www.blic.rs. ...признају да је паљењем руковођено из Косовске Митровице од стране шверцера акцизном робом... www.blic.rs.

Такође је могуће, као и у реченицама с перифрастичним пасивом формираним од транзитивних глагола, да се на агенс укаже на индиректан начин, тј. да он буде имплицитно изречен:

(7) ...у административној служби града баратано је податком... www.nezavisne.com. Отмицу је ... организовала група терориста којом је командовано из иностранства. www.novosti.rs. ...аутономном облашћу управљано је посредством војне управе... www.novosti.rs. Овим покретом руковано је из Београда. www.forum.b92.net. Тако је Дукљом владано из Прапратне, Скадра и Котора, Захумљем из Стона, Травунијом из Требиња, Босном из Бобовца. www.novosti.rs. ...порез неће бити потребан јер ће светом и појединим земљама бити владано из једног центра економске и финансијске моћи. www.politika.rs.

Иако ни у једном од примера наведених у (7) агенс није изречен директно, јасно је да је у првом примеру то неко из административне службе града, у другом нека особа или група особа из иностранства, у трећем је реч о колективном агенсу („војна управа”) итд..

5 За више о различитим морфосинтаксичким могућностима за индиректно исказивање агенса в. Танасић (2014: 197-201). 
Референт теме може имати исте денотате као и референт теме уз транзитивне глаголе (уп. Марко је уирављао машином : Марко је йоиравио машину; Ана је йріовала акцијама : Ана је йроgала акиије). Уз то, референт теме, која се у синтаксичкој структури исказа реализује као $\mathrm{NP}_{\text {ins }}$, готово да не подлеже никаквим селекционим рестрикцијама и може се, као што наведени примери илуструју, исказати иманичким синтагмама чији су управни чланови именице које припадају различитим семантичким класама (Литиа Форg, војска, оркестиар, иомораниа, шума, леииилиияа, яржава, области, железница, слика, овлашћење, ресурс, имовина, информација, робно-комеричијални зайис, ниво, узі̄ој итд.). Ово непосредно произлази из самог значења глагола уз које се носилац семантичке улоге

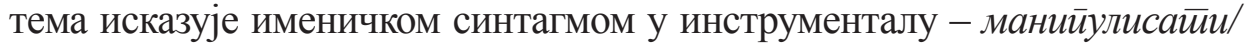

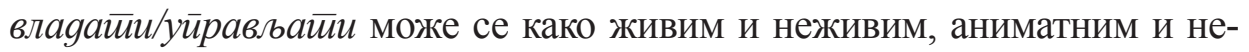
аниматним, тако и конкретним и апстрактним ентитетима. Уз поједине глаголе могућа је, чешћа или прихватљивија употреба једног или другог семантичког типа допуне, али стриктних ограничења нема. Уз сличности које постоје у одабиру референта агенса, овако широк и неомеђен избор референта теме такође указује на битну паралелу између граматикализованог објекта у акузативу који се реализује уз транзитивне глаголе и лексички, односно рекцијски детерминисаног (неправог) објекта у инструменталу уз глаголе типа „владати”.

2.2.2. Веза која се успоставља између предиката имперсоналних реченица с глаголима типа „владати” и њихових допуна синтаксички је и семантички до те мере јака да се приликом синтаксичке реализације исказа изостављање допуне, осим у врло ретким и контекстуално строго ограниченим случајевима, готово у потпуности искључује: Царевином је лоше уирављано/влаgано (и она се расйала): *Лоше је уирављано/влаgано (и она се расйала).// Привайним шумама је уїлавном нейлански іоосиоgарено, итио је gовело gо gеїраяације стианишйа: "Уїлавном је нейлански

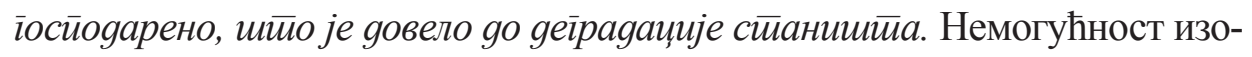
стављања допуне такође потврђује да је у овом типу конструкција природа синатаксичке и семантичке везе између предиката и допуне, како у формалном тако и у функционалном погледу, блиска оној која се успоставља између транзитивног глагола и његове допуне.

Иако различити аутори, у складу са својим теоријским опредељењем, објекатској допуни у инструменталу уз глаголе типа „вла- 
дати" приписују различит типолошки статус (па Стевановић (1979: 80-81), Поповић (2010: 247) и Арсенијевић (2007) говоре о неиравом,

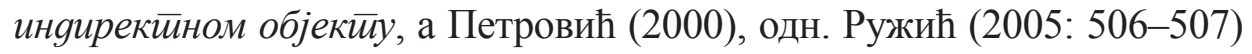
о неииииччном бесиреgлошком gирекиином објекииу), они често указују на посебност овог типа допуне и његову кореспондентност са објектом у акузативу. Тако Н. Арсенијевић истиче да: „семантичко-синтаксичко обележје обухватности објекатског појма, на који се упућује индиректно, ставља инструментал у опозицију са акузативом као падежом ... директног унутарсинтагматског односа" (ibid.: 385), а М. Ивић, говорећи о специфичностима употребе инструментала уз глаголе класе „владати”, закључује: „Овим инструменталом открива се појам који на себи трпи вршење глаголске радње, који је обухваћен овим вршењем” (ibid:: 114). Стевановић је најексплицитнији у успостављању паралеле између објекта у акузативу и објекта у инструменталу. Он тврди да нико не може да оспори да су допуне у инструменталу уз глаголе типа „владати” објекти тих глагола ,jер радње означене тим глаголима не би биле могуће без ... инструменталом означених појмова (ibid.)

Другим речима, обликом инструментала уз глаголе типа „владати" означавају се људи, предмети и апстрактни ентитети без чијег учешћа, односно постојања, реализација глаголске радње не би била могућа (не може се владати, располагати, трговати ако нема оних или онога чиме се влада, располаже, тргује), као што се ни радња правих транзитивних глагола не може реализовати без постојања одговарајућег објекта. Посебно је важно запажање М. Ивић о томе да је реч о објекту који на себи трпи вршење глаголске радње и потпуно је обухваћен њиме - управо су ово својства и објекта транзитивних глагола који се реализују у пасивним конструкцијама. Иако употреба инструментала, свакако, уноси и додатну нијансу значења - значење средства, то не мења чињеницу да глаголи из ове групе свом објекатском аргументу приписују улогу теме (или пацијенса, уп. Лийа Форg ... свеgочи како је њоме маниичлисано...), значи исту ону семантичку улогу коју својим објекатским допунама приписују и транзитивни глаголи.

2.2.3. Да је у савременом српском језику статус објекатске допуне у инструменталу уз глаголе класе „владати” врло специфичан, те да се $\mathrm{NP}_{\text {ins }}$ јавља као лексички (рекцијски) условљена варијанта обје- 
катске допуне у акузативу ${ }^{6}$ указује и постојање три типа конструкција у којима је могућа алтернација објекта у акузативу и објекта у инструменталу, при чему до промена долази само на плану морфосинтаксичке реализације исказа док семантичке улоге аргумената остају непромењене. То су конструкције у којима $\mathrm{NP}_{\text {ins }}$ алтернира са $\mathrm{NP}_{\text {acc }}$ у функцији директног објекта: 1. уз глаголе типа „даровати” (Бошко је gаровао Ану свиленом марамом : Бошко је даровао Ани свилену марамy), 2. уз глаголе типа „натрпати” (Марко је найрйао кофер сииварима: Марко је найрйао стивари у кофер), 3. уз глаголе типа „прскати” (Прскала је лице воgом: Прскала је воgу йо лииу). ${ }^{7}$ Пошто је реч о синтаксички и семантички разнородним класама глагола, могућност ротације $\mathrm{NP}_{\text {ins }}$ са $\mathrm{NP}_{\text {acc }}$ у функцији директног објекта пружа додатни аргумент за тврдњу о инструменталној допуни уз глаголе класе „владати" као лексички условљеној варијанти објекатске допуне у акузативу, што онда расветљава и могућност њихове реализације у деагентизованим конструкцијама с партиципским пасивом.

2.3. Анализа функционалних својстава имперсоналних реченица с глаголима типа „владати” у облику партиципског пасива такође указује на њихову сродност с пасивним реченицама формираним од транзитивних глагола. И један и други реченични тип употребљава се када комуникативна и реченична перспектива захтевају било потпуно уклањање агенса из синтаксичке структуре реченице, односно његову анонимизацију и повлачење са сцене, било његову демоцију, односно потискивање у позадину. При томе објекатска допуна уз глаголе типа „владати” не мења свој морфолошки лик (и даље је реч о $\mathrm{NP}_{\text {ins }}$ ) за разлику од објекатске допуне уз транзитивне глаголе која мења свој морфолошки облик и у пасивној реченици бива промовисана на позицију реченичног субјекта. Међутим, и објекатска допуна у инструменталу бива на известан начин бива промовисана - она се врло често помера на прву позицију у реченици, чиме постаје топикализована и истакнута у први план (в. 2.1.).

3. Све досад уочене структурне и функционалне паралеле из-

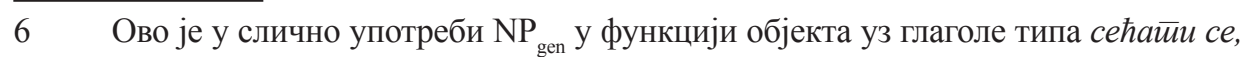
gойаћи се за коју М. Ивић (1983: 116) каже да је „условљена специфичним окружењем“. И Петровић (2000: 444) као примере за типичан беспредлошки, директан објекат наводи реченице Сећа се њеної осмеха и Држи се чињенища. За више о овим глаголским класама в. Moskovljević Popović (2000: 293-301, 2007: 70-76), Московљевић Поповић 2018). 
међу имперсоналних конструкција с глаголима типа „владати” у облику партиципског пасива и аналитичких пасивних конструкција с транзитивним глаголима указују да су ова два типа конструкција у многоме слична, као и да деле бројна заједничка својства. Упркос томе, оне се у синтаксичким описима српског језика не класификују на исти начин - док се конструкције с транзитивним глаголима типа Поменуйи су йоgащи за које никаg нико није чуо сврставају међу пасивне, конструкције с интранзитивним глаголима типа Барайано је йоgацима за које никаg нико није чуо означавају се као имперсоналне (али не и пасивне). Основни циљ овог дела рада је да се размотре разлози за овакву класификацију и изложе аргументи за њену измену.

3.1. У савременом српском језику се према формално-синтаксичким критеријумима разликују два типа пасивних конструкција - конструкција са партиципским (перифрастичним) пасивом и конструкција са рефлексивним пасивом (Милошевић 1972; Поповић 2010: 266-268; Пипер 2005: 622-625; Танасић 2014: 12, 189). За оба типа конструкција се како у старијим, тако и у новијим граматикама и језичким студијама тврди да су могуће само у реченицама са правим транзитивним глаголима. Тако, када је о партиципском пасиву реч, Стевановић наводи да „неправи прелазни глаголи ... не могу имати облика трпног придева колико ни непрелазни глаголи, па се зато у школским граматикама сврставају међу непрелазне глаголе ...” (Стевановић 1979: 325), Танасић тврди да „пасивну дијатезу исказују само реченице с прелазним глаголом у предикату (ibid., 189), а код Пипера налазимо да „прелазност насупрот непрелазности представља лексичко-граматичко обележје глагола као врсте речи, према којем се сви глаголи деле на прелазне и непрелазне, а од припадности глагола једној или другој групи зависе многа њихова синтаксичка својства - на првом месту могућност или немогућност употребе глагола у пасивним конструкцијама” (ibid., 611).

Слично је и у граматикама и студијама са других јужнословенских простора. Л. Вукојевић наводи: „Da bi glagol mogao biti pasiviziran nužan je (ali ne i dovoljan) uvjet da on svojom leksičkom projekcijom zahtijeva obvezatnu prisutnost objektne dopune (u akuzativu bez prijedloga i koja uz to nema adverbijalnu funkciju). Taj uvjet ispunjavaju tranzitivni glagoli (intranzitivni dosljedno isključuju objektnu dopunu)" (VuKOJEVIĆ 1992: 244). ${ }^{8}$

8 Уп. и К. Милошевић (1972), Katičić (2002:156), Silić и Pranjković (2007: 196), Belaj (2004), Saavedra (2007). 
Да пажњи граматичара нису промакли и примери који потврђују да је опсег језичких чињеница које се односе на партиципски пасив много шири од оног који се обично разматра, показује студија о структури просте реченице Милке Ивић (Ivić 1983). Анализирајући обличке верзије предиката у реченицама у којима вршилац радње постоји али се оставља у анонимности, она наводи и примере конструкција са трпним придевом и неправим објектом (расирављано је о йоме), као и примере конструкција са трпним придевом и сентенцијалним објектом (gоїоворено је gа сасиианак йочне у шесй) (ibid.: 76). Дефинише

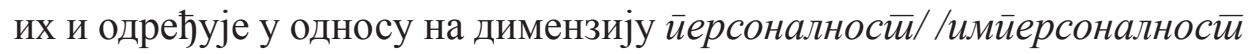
као имперсоналне реченице чији се ,предикат не подаје повезивању са субјекатском формом са којом би остварио конгруенцијски однос; у схеми: Pred -/ $\rightarrow$ Subj. + Pred.” (ibid.: 82-83). Када је о њиховој дијатези реч истиче, без даљих образлагања, да „кад објекат постоји, али је исказан као индиректан ...(и) ... кад службу објекта не врши именичка реч, већ реченица...” онда конструкције остају „ван пасивних реченичних структура" (ibid.: 76).

У дужој студији која је у целости посвећена пасивној реченици, Б. Белај нуди донекле другачију типологију. И он примере као што су У уводном излайању уйозорено је на неке gилеме и Из америчке службе указано је на борбу иройив gроїе сврстава међу имперсоналне (непасивне) конструкције образлажући то чињеницом да „u tim rečenicama predikat nije sročan sa subjektom/nominativom, kao jednim od osnovnih preduvjeta pasivizacije" (Belaj 2004: 14-16). Међутим, за реченице са клаузалним субјектом, као што су Оgлучено је gа се уйакмица оgі̄ogu и Наређено је gа се йовучемо он тврди да „ni u kom slučaju nisu bezlične jer je predikat sročan s nominativom ostvarenim subjektnom rečenicom..." и то аргументује наводећи да сложеној реченици Наређено је ga се йовучемо у потпуности одговара проста реченица Наређено је йовлачене у којој je ,glagolska imenica povlačenje u ulozi subjekta/trpitelja, a objema je rečenicama moguće pridružiti njihov aktivni konceptualni korelat... " (ibid.).

Поредећи пасивне конструкције у хрватском и бугарском језику, Д. Сааведра допушта постојање безличног пасива у реченицама типа Тук е йушено, али само када је њихов предикат транзитивни глагол, тј. када постоје и кореспондентне, како их она назива, „традиционално пасивне" реченице типа Тук е йушена лула (Saavedra 2007: 220). Другим речима, и ова ауторка сматра да је присуство прелазног глагола 
ГЛАГОЛИ ТИПА „ВЛАДАТИ” У ИМПЕРСОНАЛНИМ КОНСТРУКЦИЈАМА ...

у функцији предиката у пасивној конструкцији обавезан услов за реализацију пасива јер „с̌ak i kad je u neprijelaznoj uporabi, takav glagol sadrži u svojoj semantičkoj strukturi impliciran pacijens radnje" (ibid.).

У Синйакси савременоїа срйскої језика (Пипер и др. 2005) наводе се три примера за имперсоналне реченице с партиципским пасивом - О йоме је мноі̄о йисано.// Са овима је свриено// О йоме је оgлучено на синоћној сеgници. Ове реченице одређују се као „безличне реченице с партиципом пасива у именском делу предиката” (Пипер 2005: 605), што би значило да се анализирају као особен вид копулативних конструкција, чија је дистинктивна црта употреба партиципа пасива у функцији именског предикатива.

Свим наведеним анализама заједничко је: 1. да се у пасивне конструкције убрајају само оне у којима је предикат у персоналном (личном) облику, односно само оне у којима постоји конгруенција између субјекта и предиката; 2. да се транзитивност глагола сагледава и анализира као стриктно дихотомно категоријална, односно да се глаголи одређују или као транзитивни (могу се реализовати у пасивним конструкцијама), или као интранзитивни (не могу се реализовати у пасивним конструкцијама); 3. да се имперсоналне конструкције са интранзитивним глаголима доследно и без изузетка искључују из пасивне дијатезе. Како последњи наведени услов обухвата и глаголе који се реализују са неправим објектом, при чему се у обзир узима само формална, синтаксичка, а не и семантичка валенца предиката, имперсоналне реченице с глаголима типа „владати” у облику партиципског пасива и објекатском допуном у инструменталу се по дефинцији сврставају међу имперсоналне (непасивне) реченице.

3.2. Иако је овакво схватање пасива било доминантно у различитим школама структурализма, варијантама генеративне граматике, као и у словенској и јужнословенској лингвистици, у савременој језичкој типологији и синтаксичкој теорији прихваћени су нови, шири критеријуми за дефиницију пасива по којима се и одређени типови имперсоналних конструкција са универзално дефинисаним својствима укључују у категорију пасивних конструкција, односно у поткатегорију имйерсоналних йасивних консиирукција. По тим критеријумима, конструкција се одређује као имперсонално-пасивна: 1. ако постоји кореспондентна активна конструкција; 2. ако је реченица без граматичког субјекта (или је, као 
у неким језицима, присутан „неиспуњен” ('dummy') субјекат); 3. ако се предикат налази у одговарајућем, морфолошки или морфо-синтаксички маркираном облику пасива; 4. ако реченични члан који је носилац семантичке улоге агенс или није присутан у синтаксичкој структури исказа, или се исказује необлигаторном NP или РР у одговарајућем, граматикализованом облику; 5. ако је агенс носилац обележја аниматности, свесности и интенционалности, односно ако је реч о особи, или скупу особа (колективу, институцији); 6. ако су прагматска и дискурсна ограничења при употреби овог типа конструкција строжа него кад је реч о употреби кореспондентне активне реченице (Siewierska 1984: 93-126, Frajzyngier 1982, Abraham и Leisö 2006, Kiparsky 2013).

На основу ове листе критеријума (а понекад и нешто шире, која укључује и својства специфична само за поједине језике која се овде не наводе јер су без значаја за анализу српског језика), имперсоналне пасивне конструкције уочене су и описане у санскрту, латинском, немачком, холандском, велшком, ирском, финском, литванском, пољском, турском и канада језику, између осталих. ${ }^{9}$

Примена наведених критеријума на имперсоналне реченице с глаголима типа „владати” у облику партиципског пасива и објекатском допуном у инструменталу показује да је сваки од њих испуњен: 1. према свакој реченици наведеној у 2.1. постоји и кореспондентна активна реченица (...у Аgминистирайивној служби іраяа барайано је йоgайком... : Аgминисиирайивна служба іраяа барайала је ӣоgайком ...); 2. ниједна од реченица из корпуса нема граматички субјекат (2.1); 3. предикати свих реченица из корпуса налазе се у облику партиципског пасива; 4. ако је у синтаксичкој структури реченице присутан конституент који је носилац семантичке улоге агенс, исказан је одговарајућом, граматикализованом конструкцијом $\mathrm{PP}$ „о сиране“ $+\mathrm{NP}_{\text {gen }}$ (2.1. и 2.2.1); 5. подразумевани (имплицитни) агенс сваке од реченица из корпуса носилац је обележја аниматности, свесности и интенционалности (2.1. и 2.2.1); 6. употреба имперсоналних пасивних конструкција свакако је мање честа и подлеже већим ограничењима од употребе кореспондентних активних реченица (2.3).

4. Анализа, у првом реду значењских и функционалних, али и одређених структурних својстава имперсоналних конструкција с гла-

9 За ширу, мада и даље непотпуну листу в. Siewierska (2013). 
ГЛАГОЛИ ТИПА „ВЛАДАТИ” У ИМПЕРСОНАЛНИМ КОНСТРУКЦИЈАМА ...

голима типа „владати” у облику партиципског пасива и објекатском допуном у инструменталу указује на бројне подударности између овог типа конструкција и пасивних конструкција с партиципским пасивом које су формирају од транзитивних глагола. Додатна провера обележја ових конструкција у односу на општелингвистичке критеријуме који се користе при категоризацији реченица као имперсонално-пасивних показује да оне испуњавају све критеријуме који се за овај тип конструкција у литератури наводе. Пошто и анализа грађе и анализа испуњености критеријума дају исте резултате, следи да конструкције овог типа треба одредити не само као имперсоналне (као што је то до сада био случај у граматикама српског језика), већ као имиерсоналне йасивне реченище, а на листу језика у којима је реализација овог реченичног типа могућа треба додати и савремени српски језик.

Опис и анализа имперсоналних пасивних реченица с глаголима типа „владати” представљају само први корак у одређењу граница и обележја категорије имперсоналног пасива у српском језику. Њена адекватна, емпиријски и теоријски утемељена детерминација биће окончана тек када се начини исцрпан инвентар свих типова реченица који се у њу сврставају и дефинишу синтаксичко-семантички обрасци по којима је формирање имперсоналних пасивних реченица у савременом српском језику могуће.

\section{Извори}

www.nezavisne.com. www.b92.net. www.forum.b92.net. www.novosti.rs. www.blic.rs. www.rtv.rs. www.pravda.rs. www.benchmark.rs. iluzionist54. blogspot.com. www.scribd.com. www.static.rtv.rs. www.autonomija.info. www.mitropolija.me. www.pp-medvednica.hr. www.vasicrajko.blogspot. com. www.frontal.rs. sr.istorija.wikia.com. www.nspm.rs. www.pravoslavniodgovor.com. www.kurir.rs www.cvecaragardenia.co.rs. www.skolskisajt. in.rs. www.magazin-tabloid.com. www.rtrs.tv. www.transparentnost.org. www.doiserbia.nb.rs. http://www.vreme.com. https://www.srbijadanas.com. www.belex.rs. https://singipedia.singidunum.ac.rs. 
Јасмина Московљевић Поповић

Литература:

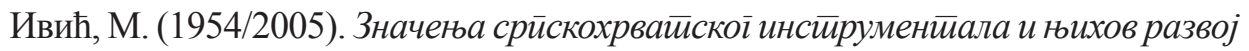

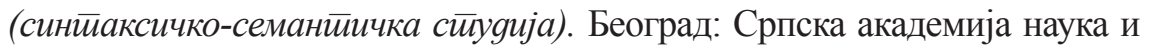
уметности - Београдска књига - Институт за српски језик САНУ.

Милошевић, К. (1972). Неки аспекти семантичког односа конструкција пасивне (са трпним придјевом) и рефлексивне у савременом језику. Къижевни језик I/3-4: 63-86.

Московљевић Поповић, Ј. (2018). О бенефактивним конструкцијама са глаголима типа „даровати”. Срйски језик XXIII: 99-115.

Московљевић Поповић, Ј. Имйерсоналне йасивне консиирукиије у савременом срйском језику. Београд: Филолошки факултет, у припреми.

Петровић, В. (2000). О предлошком објекту у српском језику. Зборник Маииие срйске за филолоіију и линївисиику XLIII: 437- 445.

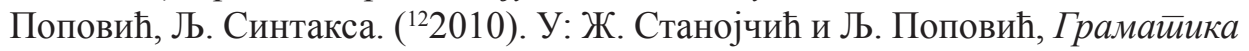
срйскої језика за іимназије и среgње школе. Београд: Завод за уџбенике и наставна средства, 204-384.

Пипер, П. (2005). Семантичке категорије у простој реченици: синтаксичка семантика. У: П. Пипер и др. Синйакса савременої срӣскої језика. Простй реченииа. Београд: Институт за српски језик САНУ, Београдска књига. Нови Сад: Матица српска, 575-982.

Пипер, П., Антонић, И. Ружић, Б., Танасић, С., Поповић, љ., Тошовић, Б.

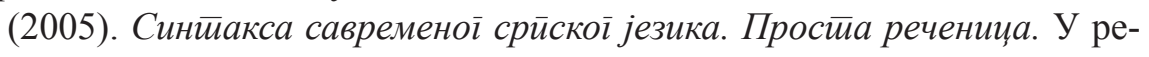
дакцији М. Ивић. Београд: Институт за српски језик САНУ, Београдска књига. Нови Сад: Матица српска.

Радовановић, М. (2007). Сйари и нови сиииси - ойлеgи о језику и уму. Нови Сад: Издавачка књижарница Зорана Стојановића.

Ружић, В. (2005). Проста реченица као синтаксичка целина. У: П. Пипер и др. Синйакса савременої срйскої језика. Простиа реченища. Београд: Институт за српски језик САНУ, Београдска књига. Нови Сад: Матица српска, 477-571.

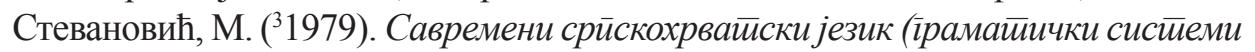
и књиюсевнојезичка норма) II - Синйакса. Београд: Научна књига.

Танасић, Срето. (2014). Синйакса йасива у савременом срйском језику. Београд: Београдска књига.

Abraham, W. и Leisiö, L. (2006). Passivization and Typology: Form and function. Amsterdam/Philadelphia: John Benjamins. 
Arsenijević, N. (2007). Tranzitivnost i padeži objekta u srpskom jeziku. Зборник Майице срйске за славистику 71-72: 377-389.

Belaj, B. (2004). Pasivna rečenica. Osijek: Filozofski fakultet.

Frajzyngier, Z. (1982). Indefinite agent, passive, and the impersonal passive: A functional study. Lingua 58: 267-290.

Ivić, Milka. (1983). Lingvistički ogledi. Biblioteka XX vek. Beograd: Prosveta.

Janda, L. (2007). From Cognitive Linguistics to Cultural Linguistics. Slovo a Smysl 8: 48-68.

Jónsson, J. G. (2009). Verb classes and dative objects in Insular Scandinavian. У: Barðdal, Jóhanna и Chelliah, Shobhana L. (yp.). The Role of Semantic, Pragmatic, and Discourse Factors in the Development of Case. Amsterdam: John Benjamins, 203-224.

Katičić, R. ('2002). Sintaksa hrvatskoga književnog jezika. Zagreb: Globus.

Kiparsky, P. (2013). Towards a null theory of the passive. Lingua 125: 7-33.

Moskovljević Popović, J. (2007). Ogledi o glagolskoj potkategorizaciji. Beograd: Čigoja.

Saavedra, D. (2007). Pasivne konstrukcije u hrvatskome i bugarskome jeziku. Lahor: časopis za hrvatski kao materinski, drugi i strani jezik 2/4: 217-241.

Silić, J. i I. Pranjković. (2007). Gramatika hrvatskoga jezika za gimnazije i visoka učilišta. Zagreb: Školska knjiga.

Siewierska, A. (1984). The passive: a comparative linguistic analysis. London: Croom Helm.

Siewierska, A. (2013). Passive Constructions. Y: Dryer, Matthew S. \& Haspelmath, Martin (eds.) The World Atlas of Language Structures Online. Leipzig: Max Planck Institute for Evolutionary Anthropology. (Доступно на: http://wals.info/chapter/107. Приступљено 8. 10. 2017.).

Vukojević, L. (1992). Sintaksa pasiva. Rasprave Zavoda za hrvatski jezik, sv. 18: 235-258. 
Јасмина Московљевић Поповић

Jasmina Moskovljević Popović

\section{Summary}

\section{INTRANSITIVE VERBS OF THE TYPE „VLADATI” ('TO GOVERN') IN IMPERSONAL PERIPHRASTIC PASSIVE CONSTRUCTION IN CONTEMPORARY SERBIAN}

This paper focuses on one particular type of construction in contemporary Serbian language - an impersonal sentence formed from intransitive verb of the type "vladati" ('to govern') in periphrastic passive construction, as its predicate, and $\mathrm{NP}_{\text {ins }}$, as its oblique complement. This type of construction is classified as impersonal (and non-passive) in both traditional and contemporary grammars of Serbian, despite morphosyntactic form of its predicate (analytic passive), its distribution, and its discourse function.

Apart from presenting the relevant corpus material, the paper offers the analysis of major structural and functional traits of this type of construction. Arguments which support its reclassification and new categorization along the dimensions of $[ \pm$ personal] and $[ \pm$ active] have been proposed. An initial analysis of the extra-linguistic and intra-linguistic processes which enable and condition the appearance of this type of impersonal passive constructions in the contemporary Serbian language has also been conducted, and questions for further research have been specified.

Key words: the verb class 'to govern', the instrumental complement, impersonal construction, passive, impersonal passive, the Serbian language 